\title{
The Application of Han Feizi's Thought to Enterprise Management
}

\author{
Min Qiu \\ School of Marxism \\ Wuhan University of Science and Technology \\ Wuhan, China
}

\begin{abstract}
Han Feizi is the representative and integrator of the pre-Qin legalist ideology, advocating the rule of law. His thoughts can be summarized as "law", "art" and "potential". Han Feizi's thought has great significance of practicability and reference to modern enterprise management. This article will discuss the management idea and method basis of Han Feizi's thought in the three aspects of "law", "operation" and "potential".
\end{abstract}

Keywords-Han Feizi; management; modern enterprises

\section{INTRODUCTION}

Han Fei (about 280 B.C. -- 233 b. c.) is an outstanding thinker, philosopher and essayist in ancient China. Han Feizi's theory of legalism provided the theoretical basis for the birth of China's first unified centralized state.

Han Feizi's thought can be summarized as "law", "art" and "potential", namely to make the law and to use the power, ultimately to strengthen the power of Kings, thus achieving the effect that "the districts deal with the tasks while the power is taken by the center; the saint holds the power and is served by the districts".

As an ancient legal treatise designed to focus on the centralization of the monarchy, there are quite a few dictatorial and despotic contents in Han's thoughts. In the absolute interest of the monarch, there are quite a few contents about the struggle between the King and the officials. He has repeatedly mentioned the need to be on guard against his subjects, because "when the subject is too distinguished, he might get a chance to master."Therefore, the subjects' team should be regularly "scattered" and their assistants should be "taken away from them", thus to reach the result that "the Lord is never to be invaded though he is not talented".

But at the same time, there are quite a lot of essence in the thought, which can provide some ideas for modern management, especially modern enterprise management. We need to discard the dregs and extract the essence from the thought works of Han Feizi to help us to improve the modern management system and methods.

This paper will discuss the management idea and method basis of Han Feizi's thought in the three aspects of "law", "operation" and "potential".

\section{METHOD: THE ORIGIN OF THE ROOT}

Han Feizi's was at a troublous age when there is great struggle between fathers and sons, husbands and wives. In that era, the "humility" and "benevolence" advocated by Confucianism were impractical and would only lead to the decline of the state. Only "law" is the "unchangeable thing", it is the only policy of uniting people and increasing cohesion. As the saying goes: the monarchy who tolerate the vicious is the one who will subjugate his country。 Being not strict on punishments will make subjects panicky and disaccorded. Also, to alleviate the punishments on crimes will also make people see a chance to bend the law to make benefits for their relatives, and violate the law without any worries, thus damage the benefits of the group.

For modern enterprises, their pressure on competition is no less than the feudal princes in the strife-torn warring states period, but even more than them. If you slack off a little, you may fall into a state of doom. The competitiveness of the enterprise comes from the strength of the enterprise organization, a perfect enterprise organization, which can gather all people's efforts and gather them in the direction of the goal, thus doubling the strength. But a business, with hundreds of internal members, can never be exactly the same on personal interests. In the running of an enterprise, there might be small groupuscules and small parties, invade the public's interests to benefit themselves; what's worse, group members may try to succeed by stamping on colleges' bodies, thus completely lose the ability to make any progress. How to run an enterprise organization, constrain the members, and finally get everyone to go to the right direction requires a really realistic set of rules and regulations, that is, "law". So as the saying goes, "When the law is strong, and the state is strong; when the law is weak, the state is weak. Legislation is the first step on the road to victory for an enterprise to survive.

Han Fei's legislation mainly emphasizes the following eight aspects.

\section{A. The Legislation Must Be Certain and Cannot Be Changed}

The rules and regulations are the yardstick of organizational discipline. To make it clear to the members of the organization that the rules and disciplines are to be obeyed, the discipline itself cannot be changed at will. Han Feizi stressed that the law must be stable, and that the law must be 
stable enough to have sufficient execution force, eventually become sufficient majesty. If the rules and regulations are not dignified, the organizational discipline will be relaxed and loose, leading to the collapse of the enterprise.

\section{B. Appropriate Legislation to Be Possibly Implemented}

The rule is that members sacrifice their freedom in exchange for the overall efficiency of the organization. Rules and regulations should serve the ultimate purpose and cannot in turn serve as a barrier to the completion of the goal. Han Feizi said, "when the standard of the master is easy to see, so it can be set up; When its teaching is easy to know, so it is used; Its law is easy to be conformed, so it can be executed." If a system is too strict, it will be difficult to achieve, and eventually it will not be able to be enforced. Only the practical system that can make a difference is one that groupmembers need.

\section{Be Clear and Don't Conflict with Each Other}

Han Feizi stressed the supremacy of the law, saying that there are no two ways of saying the same thing, and that there can be no conflicting rules in the same thing. This will not only interfere with the execution, but also affect the efficiency, and will confuse the members' thoughts and become the reason for each other to shirk off. Finally, the authority of the system itself will be shaken seriously

\section{Adequate Publicity Known by Almost Everyone}

A constitution, if no one knows it, will not be understood, will be stuck in the form, and will not really work. Han Feizi believed that "the book of the law is set in the government, and the receiver is the people". Only members remember the rules and understand the system, they can truly restrain their behavior and improve the discipline of the organization. In addition, publicity can effectively reduce the possibility of people deliberately distorting the law and playing the ball, which is called "to abide by the law and reject the judgment of the mind; set up the rules to get rid of assumptions".

\section{E. We Must Follow the Law and There Is no Way to Stretch Rules}

Han Feizi once said: "every small honesty will finally converge into the good credit, so the wise monarch is based on his credit. If the punishments and the awards are not credible, the law will not be enforced. The "credit" here is to establish the authority of execution. If you do not do by the law, then the law will exist in name only. The system itself should not be flexible, and only through the system and the implementation of regulations can the system be established with unshakable authority and un-tampered stability.

\section{F. Law Enforcement Must Be Strict, not to Force, nor to Fear Public Opinion}

Han Feizi repeatedly stressed that "the law is not to cater for the noble, and the rope of the law does not bend." A system, if it is easily changed for people, will not only make some important members cross the line, but also ignore the articles of association, which will further alienate most of the members and completely lose the ability of corporate solidarity. At the same time, a system cannot be changed by specific facts or public opinion supports. "Therefore, the state of law eliminates the public opinion but abide by law." As long as the system is still in force, it is the supreme authority, and it cannot be changed by anything. Only in this way can we be fair to each and every one of us, to and unite people.

\section{G. To Execute the Law Fairly, and to Restrain a Million People with the Same Law}

As it goes: "punishment will not detour the minister, and the good will not omit the civilian." This view is the essence of Han Feizi's "law". Only on the premise of fairness and justice, all members will voluntarily maintain the system and accept the constraints. Otherwise, the system will only function as a tool to suppress the members, which will not really enhance the enterprise vitality and the competitiveness.

\section{H. The Rule of Law Cannot Be Ruled by People}

Han Feizi's "law" is based on the theory of" evil-born" humanity, he thought that" people "itself as an unstable factor, cannot become the unchangeable foundation of the " law ". However, relying too much on the personal ethics of the manager, it is possible to be undermined by his or her will, which ultimately damages the collective interests. Han Feizi stressed that "the one who is good at using the law relies on the regulations but not people", and when the rules and regulations are well established and effective, it is far more important than a clean and honest manager. So as a business, "should attach his importance to the law but not the gifted people", all code of conduct use system itself as the final measure to set up its seriousness and majesty, can we truly a run a system effectively.

\section{OPERATION: USE OF THE TAO}

Han Feizi said, "it will not be with single the law or the operation.(" the law ")

To run a system is just as important as to make the system. If we want to run rules and regulations in an orderly way without being stuck in the form or being misused by people, the means of operating system "art" are indispensable.

Han Feizi believed that "the wise king makes the law as fair as the god and runs the regulations mysteriously. Different from the "law" which is exposed to the public, "technique" belongs to the paradoxical way hidden in the mind of the manager, which is the means and power of superior management. In itself, there is no specific writing plan, and it will not be issued to the public. It is more required that the users will play their own game according to their actual situation and should only follow certain principles.

The most important principle is that "operation" is merely the means of maintaining "law" and cannot be superior to "law" itself. "The wise master is faithful to the law" cannot "pass the law". Only the superior managers themselves take the lead to abide by the rules, and do not use various means to break the rules, so that the system can be maintained, and the 
"operation" has the value of existence. Otherwise, "art" is just a way of hindering progress, not worth advocating.

In the section of "The Law", Han Feizi made a basic introduction to the definition and main means of "operation". A man who is the master of the law, should take his job corresponding to his ability, and be true to his name; he must examine his officials' ability through his power of deciding people's life and death. That is, to supervise the coordination of the relationship among the position, responsibility, and supervision, and think that coordination of these three relationships is the main work of "operation".

The first of these three relationships is "to appoint officials by the talent". Leaders who work in complex enterprise reorganization do not have thousands of hands to work or eyes to see, thus can't do everything by themselves, as a result, it is a necessary process to separate the rights and responsibilities orderly, handing them to the right staff.

All things ultimately are independent on people to do, how to choose the right person in the right position, is then the method that managers should strive to master.

To choose and employ persons, ethics, morality, ability, reputation, and so on are just references to one's option, the key standard lies on whether can he "tries his best to work", which is whether to have the sense of responsibility, and whether can complete tasks by his ability. Only these two can be achieved, can become available. Other qualities are just added value for better completion of tasks, not the most fundamental requirement, and cannot be reversed.

In determining the general choice, then according to the "having wisdom to get anywhere", and "having the power to raise something", "being strong to overcome the enemy", the three principles, the master should supervise target personnel's planning direction, actual work ability, as well as whether his ability is qualified for work. And finally, judge the person who is qualified for the position.

In addition, the ultimate goal should be followed by the principle of employing people according to law. Han Feizi thinks that the wise master get away from the kindness, get rid of the intelligence and manage people by the rule of law. All organizational principles should not violate organizational development and discipline. If the system itself has some constrains such as a fixed tenure of the work in some position, then a suitable candidate, if you can't meet the system requirements, so no matter how good his ability is, how perfect his virtue is, should not be selected reasons, otherwise the system itself has no value.

After selecting the specific staff, the second step is to "check whether one's ability is true to his name". It is the aspect that carries out specific responsibility. Everyone has a plan before they get into the job, they imagine how to make progress and paint a rosy picture of the future. However, when it comes to the actual work, whether the words and deeds are consistent, and whether the responsibility is to be implemented according to the expectation, it relies on the manager check.

To assure the duty and carry out responsibility, there are three main methods: "see", "listen" and "defend".
To see is to watch his actions and check whether or not has he achieved the standard of prediction, which is the main means of "checking whether his ability according to his good name". However, "when the authority tries to watch, the subjects will try to cover up; when the authority tries to listen, the subjects will try to fake their voices; when the authority tries to think about all these, the subjects will try to decorate their words. The superior observes his subjects and the subordinates will also try to bewitch their superiors through lies. As a result, single observation methods cannot fully grasp a person's true dynamic. One also needs to obtain information from multiple sources and repeated proving.

To listen is to adopt his own views. Two man's wisdom is better than one's. Only by widely listening to the people's opinions, can we make the best use of the advantages and disadvantages, carry forward the advanced, eliminate the corruption, and increase the efficiency of the work. This is also a method of mutual supervision, which can make up for the "see" link, which is short in his single way in obtaining information. But the measure, though positive, does not necessarily be followed; the rules and the reasons, though perfect, is not necessarily used. As a manager, learning to listen to subordinates' opinions and suggestions is also a key quality.

To pretend is to prevent him from exceeding his powers. "A subordinate cannot be praised if he surpasses his station to make achievements." Surpass one's position will not only interfere with people in other departments and affect the efficiency, what's more, it functions to prevent officials of different positions to make an alignment and conceal the superior together, which provides room for corruption. It is only when the "party members are not allowed to be together" that they can provide an appropriate external environment for the development of enterprises.

After choosing the right person and use the good person, the master cannot rest easy. To achieve the ideal status where "his morality spreads to all over the world and his virtue passes down to thousands of generations", one needs to take in hand the deciding power of one's life and death and supervise officials all the time. He needs to urge them to work hard, inspect them to be innocent and the test them in the form of performance.

As a manager, it is more important to "reward and punish" the subordinate members than to "judge by the law" and supervise them. Those who are slack in their work and who fail to achieve their goals should be punished, and those who have achieved their goals should also be rewarded, finally achieve the goal that "getting rich through hard work and becoming noble through good performance". In this way, can the authority greatly arouse the enthusiasm of employees, create value for enterprises more actively, and deter those who do not act or even hinder their progress.

As a kind of "paradoxical way", Han Feizi has taken the dark attitude for operation of keeping secret inside the heart. It is said that "the operation will not succeed if the decisions are let out". There are more strokes not worth us learning to caution the subjects, even "the dubious edicts and ambassadors, ask questions with answers in mind, and confuse the right and 
the wrong". We should learn what is good for us, discard what is harmful to us, and learn with critical spirit to achieve greater harvest.

\section{Potential: Highest PURSUIT}

In the eyes of Han Feizi, the so-called "law" and "operation" are all steps to achieve the "potential". Managers who want strict enforcement of orders and prohibitions can supervise members by legislation and regulations, but the cost is too high, and the effect is not good, with a bit slack the situation will relapse. So, we need the potential.

"Potential" is not a natural form, "the potential has countless variations."Han Feizi believed that the formation of potential mainly is "two handles". The so-called two handles are punishments and awards. The "second handle", which is to reward and punish, is a weapon for managers to assess. Han Feizi believed that "everyone who rules the world, must be human. The favor is good and evil, so the reward is available. It is because of the instinct of good profit to avoid harm that the "two handles" can be used. Managers flexibly use the "two handles" to establish organization system, perfect the organizational discipline, can eventually makes each member maximally play to the subjective initiative, actively create value, and move forward without rewards and punishments, or supervision, "he said.

"The state is the car while the potential is the horse."The so-called "potential" is the sword of Damocles, which stands in the heart of all the members, and it will fall at any time, so it is necessary to be discreet and behave. Han Feizi believed that law and means were the last resort, and they would not be enforced unless they were a must. If you can, through the "law" and "operation", make people know the law and understand the law, and further respect and worship the law, and can consciously abide by the law, "To use the operation to know the vicious and to use the punishments to prohibit punishments", then achieve the fact that "Make the progress with little efforts and make the orders work with little punishments." Ultimately, we can achieve the ideal state that "the superior and the subordinate can have a good relationship", "the wise ones dare not deceive the king while the fool ones cannot give up, and all things will not have errors."

\section{CONCLUSION}

To sum up, Han Feizi believes that "law", "operation" and "potential" cannot be disregarded. To make the law is the foundation. Legislation is the first step on the road to victory for an enterprise to survive. Operation is the way to use it. Make the system and operate the system is indispensable for an enterprise."Operation" is the means of operating system."Potential" is the highest pursuit. In the eyes of Han Feizi, the so-called "law" and "operation" are all steps to achieve the "potential". Therefore, "law", "potential" and "operation" must be combined together to make a flexible enterprise.

Traditional culture is our most precious resource, inheriting its essence is the responsibility of every Chinese descendant, and it is the best way to inherit its essence and make connections to today's enterprise management. The three statements summed up by Han Feizi: the "law", "operation" and "potential", are still thought-provoking after two thousand years, having great significance of reference to the management of the modern enterprise. As an enterprise of a new era, to study and understand the essence of Han Feizi's thought and apply it flexibly to the management of enterprises will definitely bring new development and new vitality for the enterprise, promoting the enterprise to make greater achievements and glory.

\section{REFERENCES}

[1] Han Feizi, 2015 Edition of China Book Bureau.《韩非子》，中华书 局 2015 版。

[2] Chen Qiyou. Interpretation of Han non-subset [M]. Shanghai: Shangha People's Publishing House, 1974. 陈奇猷.韩非子集释[M].上海：上海 人民出版社， 1974.

[3] Chen Qiyou, Zhang Jue. Introduction of Han Feizi [M]. Chengdu: Bashu book club, 1990. 陈奇猷, 张觉.韩非子导读 $[\mathrm{M}]$.成都：巴蜀书 社, 1990.

[4] Guo Dan, Chen Jie. Topic of ancient Chinese literary history [M] Shanghai: Xuelin Press, 2005. 郭丹, 陈节.中国古代文学史专题[M] 上海: 学林出版社, 2005

[5] Wang Jimei. The influence of han feizi's rule of law on later generations [J]. Journal of Chongqing Institute of Science and Technology, 2007 (4). 王吉梅.韩非子法治思想对后世的影响[J].重庆科技学院学报, 2007 (4).

[6] Dai Shu. "Law", "Potential", "Shu" -- Han Feizi’s Thought on the Rule of Law of [J]. Journal of sun Yat-sen University, 1998 (5). 戴㯟. “法”、“势”、“术”一一略论韩非子的法治思想 [J].中山大 学学报论丛, 1998（5）. 